\title{
The place of the family of origin in romantic relationships of adults with intellectual disabilities
}

\begin{abstract}
Agnieszka Żyta, The place of the family of origin in romantic relationships of adults with intellectual disabilities. Interdisciplinary Contexts of Special Pedagogy, no. 29, Poznań 2020. Pp. 25-44. Adam Mickiewicz University Press. ISSN 2300-391X. e-ISSN 2658-283X. DOI: https://doi.org/10.14746/ikps.2020.29.02
\end{abstract}

The family in the lives of people with intellectual disabilities is not only their closest and most essential social group, but often also their basic or even the only source of support in everyday life from childhood to the late old age. In a situation of adults with intellectual disabilities who start a new romantic relationship (of a formal or informal nature), the family of origin may play different roles and occupy different places in their everyday lives. The research using the phenomenographic method of qualitative research on experiences related to being in long-lasting romantic relationships conducted with adults with intellectual disabilities allowed the author to show the place of family members (parents, siblings, extended family) in their everyday lives and in their relationships with partners.

KEY WORDS: Intellectual disabilities, adults, families, romantic relationships

\section{Introduction}

Enjoying, building and maintaining good emotional relationships make an important aspect of human life that positively contributes to happiness and psychological well-being. For people with 
intellectual disabilities, as with others, such relationships are one of basic needs. Many adults seek close intimate contacts and build friendly and romantic relationships that may or may not involve sexual contacts. Some of them marry each other, others simply live together, and still others (the biggest group of all) have girlfriends or boyfriends. Not every romantic relationship entails sex. For some individuals, just being 'a boyfriend/girlfriend', meetings, holding each other's hands and hugging are enough; others make serious efforts to move in together, marry and/or have children. ${ }^{1}$ Their families of origin, especially parents, and therapists from institutions in which they study, work or sometimes live play an important role in helping them to prepare to be in and maintain a relationship. Families are the foundation and core of each society as a source of support for their members. For people with intellectual disabilities, their families' providing emotional and physical support is of essential importance throughout their lifetimes. Parents are usually concerned about any manifestations of sexuality of their children with intellectual disabilities. This fear is connected with the lack of self-reliance, potential abuse, pregnancy and the need to take care of the baby. ${ }^{2}$ In this light, many families are anxious about relationships of their intellectually disabled adolescent and then adult children with the opposite sex and oppose marriages or civil unions. ${ }^{3}$ Meanwhile, regardless of their relatives showing approval or not, adults with intellectual disabilities form more or less formalized or lasting relationships, sometimes involving cohabitation or having children. It seems essential to investigate the role families of origin

${ }^{1}$ L. Walker-Hirsch, Building relationships/social and sexual development, In: W.I. Cohen, L. Nadel, M.E. Madnick (ed.), Down Syndrome. Visions for the 21 ${ }^{\text {st }}$ century, A John Wiley\&Sons, Inc., New York 2002, pp. 310-312; K.D. Keith, R.L. Schalock, People speaking for themselves. In: R.L. Schalock, K.D. (ed.), Cross-cultural quality of life: Enhancing the Lives of People With Intellectual Disability. American Association of Intellectual and Developmental Disabilities, Washington, 2016, p. 46.

${ }^{2}$ A. Krause, A. Żyta, S. Nosarzewska, Normalizacja środowiska społecznego osób z niepetnosprawnością intelektualną, Wydawnictwo Edukacyjne Akapit, Torun 2010.

3 J. Kruk-Lasocka, W. Antosz, Koszula i krawat. Obrazki wyłaniającej się dorostości, Oficyna Wydawnicza „Impuls”, Kraków 2018, p. 58. 
play in building and supporting romantic relationships of adults with intellectual disability, especially with respect of the latter becoming independent actors in their own lives.

\section{Families in the context of romantic relationships of those with intellectual disabilities}

Empirical research shows that intimate human relationships, including romantic relationships with a various degree of intensity, from friendly feelings to long-term relationships to marriages, play an important role in the lives of those with intellectual disabilities and the way they function psychosocially. ${ }^{4}$

Conducted by B. English and associates 5 , a meta-analysis of the scholarship on romantic relationships in individuals with intellectual disability has revealed certain external limitations and factors that support formation and existence of such relationships. These include attitudes of the families of origin. Research results point to both prohibitions from carers, who thwart romantic relationships, and actions that help those with intellectual disability play the role of a girlfriend/boyfriend/partner or a husband or wife.

Those without disabilities have a huge impact on romantic relationships in question, including by permitting their relatives to pur-

${ }^{4}$ R. Kijak, Dorośli z głębsza niepetnosprawnościa intelektualna jako partnerzy, matżonkowie i rodzice, Wydawnictwo naukowe UP, Kraków 2016; M. Parchomiuk, Seksualność człowieka z niepetnosprawnościa intelektualna, Oficyna Wydawnicza "Impuls”, Kraków 2016; B. English et al., Views and Experiences of People with Intellectual Disabilities Regarding Intimate Relationships: A Qualitative Metasynthesis. "Sexsuality and Disability" 2018, No. 36; D. Krzemińska D., Być para z niepetnosprawnościa intelektualna. Studium mikroetnograficzne w kontekście teorii postkolonialnej Homiego K. Bhabhy, Oficyna Wydawnicza „Impuls”, Kraków 2019; A. Żyta, K. Ćwirynkało, Zwiazki uczuciowe osób z niepetnosprawnościq intelektualna, Wydawnictwo Uniwersytetu Warmińsko-Mazurskiego, Olsztyn 2020 (paper in press).

${ }^{5}$ B. English et al., Views and Experiences of People with Intellectual Disabilities Regarding Intimate Relationships: A Qualitative Metasynthesis. "Sexsuality and Disability" 2018, No. 36. 
sue a relationship (if it is thought of as needed and appropriate) or forbidding this if it seems threatening or dangerous. In this respect, a particular role is played by families of origin, especially parents, who are usually reluctant towards long-term relationships or legal formalization of such relationships and, most of all, possible parenthood. They are mostly concerned about the future and consequences of romantic relationships (having sex, procreation, social stigmatizing, their child being hurt by their partner). This kind of attitude also results from one's being incompetent to assess the real capacity of the disabled and the stereotypical approach to the capabilities of these individuals as regards their understanding of love and the capacity of being in a long-term relationship is concerned. The significance of romantic emotions and feelings and the need for love and sexual needs as well as parenthood needs in those with intellectual disability is belittled and repressive practices are used by the relatives, including forcing them to end the relationship or forbidding them to resume it. ${ }^{6}$ Meanwhile - as stressed by I. Myśliwczyk in his research projects ${ }^{7}$ - recognition, acceptance and approval from relatives positively contributes to the involvement in social life and helps individuals improve their social and civic competence. Arguably, this also has a positive impact on personal relationships, including romantic relationships, as it creates a climate marked by a sense of safety, eliminates the sense of solitude and supports self-appraisal and self-esteem of an adult with intellectual disability. ${ }^{8}$

${ }^{6}$ M. Parchomiuk, Seksualność człowieka z niepetnosprawnościa intelektualną. Oficyna Wydawnicza „Impuls”, Kraków 2016.

7 I. Myśliwczyk, Uznanie dorosłości człowieka z niepetnosprawnością. Studium socjopedagogiczne narracji osób z głębszą niepetnosprawnością intelektualna w stopniu głębszym. Oficyna Wydawnicza „Impuls”, Kraków 2019, p. 263.

${ }^{8}$ L. Walker-Hirsch, Building relationships/social and sexual development, In: W.I. Cohen, L. Nadel, M.E. Madnick (ed.), Down Syndrome. Visions for the $21^{\text {st }}$ century, A John Wiley\&Sons, Inc., New York, 2002; K.D. Keith, R.L. Schalock, People speaking for themselves, [in:] R.L. Schalock (ed.), Cross-cultural quality of life: Enhancing the Lives of People With Intellectual Disability. American Association of Intellectual and Developmental Disabilities, Washington 2016; A. Żyta, K. Ćwirynkało, Związki 
R. Kijak ${ }^{9}$ argues that what plays a significant role in relationships pursued by individuals with intellectual disability are family ties and the sense of warmth and comfort of home along with the attitude the family of origin has towards the individual's building a romantic relationship and becoming a parent. He also argues that the support from the closest ones, including the family, is more conducive to the sustainability of a relationship than the partners' personality traits. Now, the couples who live together with their families of origin enjoy a lower degree of independence, decisionmaking capacity and capacity to plan their autonomous future.

The experience of those with intellectual disability in the context of sexuality and personal relationships, also addressing contacts with their families of origin, has been addressed by scholars such as E. White, R. Barnitt ${ }^{10}$ and K. Johnson and collaborators. ${ }^{11}$ E. White and R. Barnitt argue that parents do provide guidance to couples regarding daily challenges (such as chores, expenses and care for others), but they do not talk about sexuality to them.

Since relationships with families of origin are so important in building and sustaining romantic relationships, it seems essential to look into the experience of adult individuals with intellectual disabilities and see how they view the presence of their closest ones in the context of their romantic relationships.

\section{Methodology of author's own research}

The present inquiry looks at experiences among adult individuals with intellectual disabilities as regards romantic relationships

uczuciowe osób z niepetnosprawnością intelektualna, Wydawnictwo Uniwersytetu Warmińsko-Mazurskiego, Olsztyn 2020 (paper in press).

${ }^{9}$ R. Kijak, Dorośli z głębsza niepetnosprawnościa intelektualna jako partnerzy, matżonkowie i rodzice. Wydawnictwo Naukowe UP, Kraków 2016, p. 155.

${ }^{10}$ E. White, R. Barnitt, Empowered or Discouraged? A Study of People with Learning Disabilities and their Experience of Engaging in Intimate Relationships. "British Journal of Occupational Therapy" 2000, No. 63(6), pp. 270-276.

$11 \mathrm{~K}$. Johnson et al., Living safer sexual lives: research and action. Tizard Learning Disability Review, 2002, No. 7(3), pp. 4-9. 
and the significance they attach to those experiences. The present research report is part of a broader study. ${ }^{12}$

This research has been aimed at demonstrating the specific nature of experiences among adults with intellectual disabilities regarding their intimate relationships in the context of their contacts with their families of origin and to reveal the significance the respondents attach to those experiences.

The research has been driven mainly by this question: What are the experiences related to initiating and functioning in romantic relationships among those with intellectual disabilities in the context of their contacts with their families of origin and what is the significance attached to those experiences among those individuals?

Specific problems have been as follows:

- What is the role played by both partners' families of origin in their daily life?

- What are the relations between those with intellectual disabilities and their families where the former are in romantic relationships?

- What do adults with intellectual disabilities think of the level of support they and their intimate relationships receive from their extended families?

To pursue these research goals and address the research questions, the phenomenographic qualitative research method has been used. 13 "Phenomenography is concerned with various qualitatively

12 The research concerns emotional and intimate relationships in those with intellectual disabilities and has been presented in: A. Żyta, K. Ćwirynkało, Zwiazki uczuciowe osób z niepetnosprawnościa intelektualna, Wydawnictwo Uniwersytetu Warmińsko-Mazurskiego, Olsztyn (paper in press). The aspect in question, that is the role of the families of origin in the lives of both partners of a romantic relationship, including one with intellectual disability, has not been discussed in the said monograph.

${ }^{13} \mathrm{~F}$. Marton, Phenomenograpgy - describing conceptions of the world around us, "Instructional Science" No. 10, 1981, pp. 177-200; F. Marton, Phenomenography - A research approach to investigating different understandings of reality, "Journal of Thought", vol. 21, No. 3, 1986, pp. 28-49; F. Marton, Phenomenography: Exploring different conceptions of reality, [in:] D.M. Fetterman (ed.), Qualitative approaches to evaluation in education: The 
different ways used by individuals to experience phenomena and think about them and to think about mutual relationships between humans and the world". ${ }^{14}$ The analysis of the collected content has been based on elements of theory driven by Katy Charmaz ${ }^{15}$, with respondents' statements analyzed against their context and based on the procedure of the phenomenographic procedure. ${ }^{16}$

Partially structured interviews have been conducted with 35 adults with intellectual disability (mild to severe), who have been in an intimate relationship with another person for at least 12 months. The research covered a total of 14 couples and 7 individuals (6 women and $1 \mathrm{man})$, in case their partners could not take part in the research project, who at that time were or previously had been in long-term relationships. Some of the respondents included individuals married, living together as well as those living separately who considered each other as partners of a lasting romantic relationship. The individuals subject to this research project lived in the Warmian-Masurian Region and were aged between 23 and 61 (15 men and 20 women).

The research project took into consideration the guidelines for interviewing those with intellectual disability and ethical principles regarding anonymity, subjectivity and proper interview conditions. ${ }^{17}$

silent scientific revolution, New York, Praeger, 1988, pp. 176-205; F. Marton, Phenomenography, [in:] T. Husén, T.N. Postlethwaite (ed.), The International Encyclopedia of Education, Issue 2, vol. 8, Oxford, Pergamon 1994, pp. 4424-4429; R.G. Paulston, Pedagogika porównawcza jako pole nakreślania konceptualnych map teorii paradygmatów, [in:] Z. Kwieciński, L. Witkowski (ed.), Spory o edukację. Dylematy $i$ kontrowersje we wspótczesnych pedagogiach, Wyd. IBE-Edytor, Warszawa-Torun 1993, pp. 25-50.

${ }^{14}$ R.G. Paulston, Pedagogika porównawcza jako pole nakreślania konceptualnych map teorii paradygmatów, [in:] Z. Kwieciński, L. Witkowski (ed.), Spory o edukacje. Dylematy $i$ kontrowersje we wspótczesnych pedagogiach, Wyd. IBE-Edytor, Warszawa-Toruń 1993, p. 41.

${ }^{15}$ K. Charmaz, Teoria ugruntowana. Praktyczny przewodnik po analizie jakościowej. PWN, Warszawa 2009.

${ }^{16}$ A. Męczkowska, Fenomenografia jako podejście badawcze w obszarze studiów edukacyjnych, "Kwartalnik Pedagogiczny” No. 3(189), 2003, pp. 71-89.

${ }_{17}$ Cf. A. Żyta, K. Ćwirynkało, Związki uczuciowe osób z niepetnosprawnością intelektualna, Wydawnictwo Uniwersytetu Warmińsko-Mazurskiego, Olsztyn 2020 (paper in press). 


\section{Analysis of author's own research}

The analysis of interviews conducted with adults with intellectual disability who are in formal or informal romantic relationships points to several types of relationships based on the role of the family in the lives of the individuals in question and acceptance or rejection perceived by the individuals in question. The results of the conducted research have been presented in the form of quotes of respondents' statements, accompanied by interpretations. This study has aimed to delineate an overall pattern indicated by investigation of a specific phenomenon, that is the role of the family of origin in romantic relationships pursued by those with intellectual disability.

\section{Relationship as a way to escape the family of origin}

The analysis of several respondents' relationship history has shown that they often recalled their family members in a negative way - due to parents' wrong behaviour (alcohol abuse, domestic violence) or a sense of having been treated unfairly or rejected (unfair treatment compared to one's siblings, and material and mental needs not having been met). At times, respondents observed that their having been put in a special institution with a dormitory and having rare contacts with their carers is a symptom of poor treatment. Those with such views of their family situation would avoid contacts with their families of origin and focus on their partners, instead.

Poor childhood experience often causes resentment towards parent(s) and dissatisfaction with one's past and is used to justify life decisions. Some of the respondents would recall some pathological behaviours of their closest ones (alcoholism, psychological and/or physical violence), and view their life (for example completion of a special school) as a result of inadequate support as children. In such situations, families are not regarded as a source of any kind of support, and the respondents stress the absence of ties and 
unwillingness to maintain the relationships with their families of origin. Their partners became the closest one and, in many cases, the only person who satisfies their physical and psychological needs.

My mum would drink a lot. She drank daily. She didn't care if was hungry or not. They laughed that I could feel my father coming. I would open my eyes upon his arrival; contrary to my mother's arrival [she clenches her eyes]. My father was always cool. He bought me a lot of stuff and spoiled me all the time... [...] Should I argue with my mum, we would have killed each other. I would argue with her all the time. When I grew older, I didn't let her push me around. I didn't get to live with her for too long. I spent a lot of time at the dormitory. I would see her on holidays. Not always. Once, I went to see her on a weekend and came back right away. She can throw a tantrum. $(1 / 1 / K)^{18}$

Besides the pathological behaviour, the lack of good interpersonal contacts and a sense of being treated unfairly within families of origin (e.g. being abused financially) make those individuals avoid contacts with their families. In such situations, a new relationship (especially a formal one) comes as a source of additional problems as far as relationships with families of origin are concerned. This can exacerbate conflicts and increase the sense of unfair treatment, and individuals in question might also break close contacts.

I used to visit her every week, twice a week; now, I see her when I have to. My mum was so good to me that she made me give her some of my disability pension. She threatened to sue me. Some time ago, I learned that my mother allocated this house to my brother in her will. She has donated the house to my brother without telling me anything. I learned about that from my nephew. I was pissed off and cut any contacts with my brother and my mum, but then, a few months later, we needed help with placing tiles and refurnishing the house (2/4/M)

18 All statements made by the respondents are quoted in an original form. 
In the reported situation, the male respondent feels he has been treated unfairly compared to his brother and feels that he is used financially.

In this group of relationships, respondents do not expect any kind of support from their extended families and they do not feel the need to maintain contacts with them. Their partner and, sometimes, their partner's family became their closest individuals. The analysis of their statements helps us observe that the relationship is often meant to compensate for the sense of rejection and solitude.

\section{Relationship as a difficult situation for the family of origin (a source of ambivalent feelings)}

Rarely are romantic relationships in those with intellectual disability entirely accepted by the closest ones. Besides attitudes that show acceptance and willingness to provide support or even joy at the disabled family member finding a close person and building a relationship with them, the reluctance and fear of potential problems often crop up (pregnancy, financial problems, the closest one being abused etc.). In many cases, the responses from the relatives vary a lot and are heterogenous. Sometimes, the acceptance grows as a romantic relationship develops, especially when it turns out that the relationship is sustainable and a couple copes well with daily demands. Not all family members are happy with their child/brother/sister forming a relationship (especially when they think that their partner is an irresponsible person or their closest one may be abused in that relationship).

Certainly, the husband's brother and sister-in-law, and the children, came to accept it fairly quickly. Things were not so easy with the mother. By now, she has come to accept that. She had no choice. I took her son, who was supposed to live with her to the end of his life. My own family approaches this in a variety of ways. They seem to pretend something in a way. Sometimes they accept that, and then they don't when they see something they don't like. $(2 / 3 / \mathrm{K})$ 
In the case of families that show inconsistent attitudes towards relationships formed by their disabled family members, various kinds of dynamics emerge - from avoidance of contacts and reluctance to rare contacts to relationships based on expression of positive emotions and involvement in daily life. Usually our respondents describe most willingly those family members who seem dearest to them.

He has a nice sister. She always greets me with a kiss in a cheek. She hangs out with me and then we go somewhere together. We have a walk or something. We go to the beach together $(11 / 18 / \mathrm{K})$.

This kind of dynamics may be marked by certain ambivalence in the way various family members approach the relationships and their hesitation and attitudes changing based on the duration of relationships and additional external factors. Under such circumstances, individuals with intellectual disability do not feel confident and experience no support from their relatives. Their sense of connection with their extended family and a sense of safety may be disturbed. Sometimes, families' attitudes to relationships may be inconsistent. Their changeability may be taken for attempts to manipulate a given individual and interfere with the life and matters of a given romantic relationship. In the case of such family dynamics, our respondents tend to focus on relationships with those family members who are kind to them - they regard them as the closest individuals and seek to stay in touch with them, and when needed ask them for advice or support. Such persons become significant individuals to them; they are authorities or role models in various critical situations or problems in romantic relationships.

\section{Relationship as a way to expand the group of informal support}

Another kind of relationship, where individuals who are part of a relationship are accepted, liked and supported by their relatives, is a relationship as a way to expand the group of informal support. 
Our respondents talk about their positive feelings towards their closest ones (including their partner's family) and a sense that they are positively received and treated by those people. The respondents generally feel close affinity with members of the families of origin, have good childhood memories, appreciate their help and support and are happy to be part of their lives. In this way, the circle of individuals who are significant to them and who they think of as sources of possible support is being extended. They enjoy the dynamics with their own family and one of their significant others and are happy to spend their free time with them.

My parents like [...] a lot. His mother as well. We hang out with Justyna a lot since she has a boyfriend, too. We refer to her as <a mother-in-law>. Michat sometimes refers to my mother as his mother-inlaw, too. $(3 / 5 / \mathrm{K})$

As with the previous group, the sense of acceptance is not always present - in this case from the partner's family - from the very beginning. Our respondents claim that the beginnings were difficult. Some reserve or even aversion might be felt by them during the early days of a relationship, but their dynamics significantly improve as the relationships unfold and the contacts grow more intimate.

Later, I learned that his mother had not wanted that. Because I am illiterate. So she said: "Why do you want someone like that?" But I learned about that later on. He later told me about that, he didn't tell me early on. It happened a year into our relationship. Now, my mother-in-law is better than my own mother. She has little money to buy things, but she always buys a little Christmas gift. She is so... you know what I mean? $(14 / 22 / \mathrm{K})$

Building good dynamics is equally about receiving support and giving it. Besides using their family support, the disabled have an opportunity to be a source of support for others and contribute to good ties by a range of activities that are part of their daily lives. 
Undoubtedly, this positively contributes to their romantic relationships and also improves the sense of safety and supports these individuals' self-determination and their identity of being an adult person who is useful, responsible and fully contributes to a family life.

M.'s mother likes me a lot. She likes to approach me with many matters. I refer to her as my mother because she asked me to. She asked me for that in the very beginning. And she is like a mother should be. She's good, she helps me. My sisters are jealous of my good mother-inlaw [she is laughing]. Theirs are not so good. I don't know why it is so with me. My [partner] says I am kind-hearted. Because I like to share things with others; whenever I have a cake, I will share it. I share it with my mother... my mother-in-law. (15/24/K)

This kind of relationships point to high significance of good dynamics with families of origin of a given individual and their partner. This has a positive impact on the wellbeing of those individuals and facilitates better functioning of their relationship. In difficult situations, the respondents of this group feel they are supported and accepted and want to be the source of support for their closest ones.

\section{Thwarted/ruined relationship as a result of extended family's actions}

Two persons, a woman who divorced her husband and a woman who broke up with her partner and a father to her child, claimed, while discussing the main roles of their families in their romantic relationships, that their families were the main or one of the major reasons behind their break-ups. One can refer to these relationships as thwarted or ruined.

The two female respondents recall family's aversion (families of male partners in both cases), manifesting itself with critique, teasing or even physical violence. They provide detailed descriptions of teasing, and stress that these people were main reasons behind break-ups. 
They said that I didn't care about the house at all, that I didn't clean the house, didn't cook, that his mother did everything; how come his mother, I thought? Initially, I cooked as well as I could, I cannot say I am good at it. I cannot cook as well as his mother does. Not everyone can do that so well. I would cook as well as I could, but it was not tasty... My ex-mother-in-law would pour the soup under my blouse and throw pierogis on my head. My ex-husband said... That they were in the fridge for too long, but they were not...

After the wedding, I just faced prohibitions and punishments. His mother and his family were behind that... She destroyed our marriage, she just did that, in this way... The ex-mother-in-law said that she would not let anyone break a marriage, and then she did it herself... If we lived separately, it would be the same... She would interfere with us; she would certainly visit us or my ex-husband would call and report things to her... $(18 / 29 / \mathrm{K})$

A similarly difficult situation is revealed by another narrative, from a woman who gave birth to a child that was taken from her by the court. Presently, the childcare is provided by her ex-partners' parents.

As I'd given birth in G., the District Family Support Center arrived and took it from me. Otherwise, the child would face an orphanage. They knew my conditions as they had checked things before. I wanted to keep the baby. Of course. But I did not have proper conditions to do that. His mother took it [...]. They are so mean, both him and her (author's note: the girl's carers). My partner lives with his parents. Where should he live? But if they die, the child will be taken from him... Because he doesn't work [...]. Nobody helps me. Who should help me? I don't want anybody. People are mean here. $(5 / 8 / \mathrm{K})$

Women in both cases view their partners' families in a very negative way. Not only do they complain about the lack of support from them, but they also accuse them of actions that had adverse impact on their own functioning (this is especially the case with the first woman) and broke their relationships. 
To sum it up, the analysis of the statements regarding those with intellectual disability with their generational family members allows us to distinguish between three basic types:

- Symbiotic relationships, based on constant presence and support (characterized by close physical contact, e.g. living together or in one neighborhood, constant involvement in daily life, support in daily and emotional lives - frequent conversations, expression of mutual feelings and mutual concern);

- Formal relationships, based on sporadic contacts with insignificant emotional charge (oftentimes, the reason for this is both the geographical distance between individuals and the lack of strong emotional ties or the fact that the partner of an adult child with intellectual disability is not accepted);

- Unrealized relationships, marked by the lack of close bond or personal contacts or even virtual ones. This is mostly due to the relationship having been broken before, the child with intellectual disability having been 'rejected'.

The way our respondents have assessed the support they or their partners receive from their closest ones varies, too. In the light of their subjective assessments, the respondents can be divided into two basic groups:

- Those who notice the presence of their families of origin in the life and functioning of their romantic relationships (these are the people who describe the mutual contacts in detail, are generally happy with them, regard their closest ones as authorities in many daily life matters);

- Individuals who have a negative view of the support they receive from their family of origin (two sub-groups can be distinguished in this case: those whose relatives are involved with their lives, but their efforts are not aimed at providing support or are aimed at obstructing or compromising the romantic relationship in place, and those who do not have relationships with their families of origin and do not feel they receive any kind of support from them). 


\section{Discussion}

Families of origin are individuals of great significance in the adult lives of those with intellectual disability and usually have a high bearing on those individuals' attitude to pursuing a romantic relationship, sustainability of that relationship (by providing support, facilitating or hampering the romantic relationships) and the individuals in question playing their role as partners with some degree of success. They are a kind of role models and points of reference for how to play the role of a girlfriend/boyfriend/partner/ wife/husband or a parent and - with the lack of nationwide system solutions - often also the source of financial, organizational, informational and emotional support. Additionally, good contacts with one's family of origin improve the wellbeing and self-esteem in those with intellectual disability. This research project has demonstrated that the range of attitudes of the family members seem very broad: from devaluating one's being in a relationship (obstructing emotional and intimate relationships; interfering with relationships; forcing individuals to end the relationship or, in the case of a pregnancy, to abort a child or give it up for adoption) to disablism and discrimination (treating the disabled as dependent and needing constant care and support and required to justify all of their decisions) to attitudes marked by acceptance and rational support (a family member being receptive to the needs of those in romantic relationships, providing support where needed without interfering with a relationship or doing a task for a given person where not necessary). ${ }^{19}$

The intense presence of families of origin in the relationships of the adult relatives with intellectual disability is definitely due to the nature of this group. Since they are closely connected to their families (which results both from emotional conditions and practical requirements), they rarely feel they are independent or emancipated

${ }^{19}$ Cf. M. Parchomiuk, Seksualność człowieka z niepetnosprawnościa intelektualna, Oficyna Wydawnicza „Impuls”, Kraków 2016, p. 142. 
enough to 'break away' from their parents and siblings. Family is constantly present in their lives. ${ }^{20}$ On the one hand, their relatives see no chance for their disabled adult children or brothers/sisters to become a fully self-reliant and independent individual, which stems from their view of how these individuals function cognitively and socially and the state support system in place. Their concern is often a manifestation of a strong bond and fear that their son or daughter can be hurt or abused. On the other hand, the adults with intellectual disability are in many cases not ready in emotional, social and behavioral terms nor, in fact, do they see the need to emotionally and practically separate themselves from their families of origin, even though they often voice the significant need to become independent and self-reliant while pursuing a romantic relationship. They have not been prepared or taught to be individuals who can make decisions for themselves, who can make choices and impact various matters. Their experiences vary enormously, depending on the way the functioning of the whole family system, the presence of additional disorders or factors that have negative impact on the mental wellbeing of the family members in question (alcoholism in one of family members, domestic violence, conflicts with law and financial helplessness). In those families, disability of a family member is usually an additional factor that obstructs proper relations. Other families cope with daily life problems more or less successfully, adapting to the situation where their adult son or daughter with intellectual disability comes to pursue a romantic relationship. Sometimes, this is a difficult or even unacceptable situation to them, but there are also examples of families adapting to a new form of contacts, consisting in support provided to the couple (both in organizational, financial and emotional terms). Statements provided

${ }^{20}$ Cf. A. Krause, A. Żyta, S. Nosarzewska S., Normalizacja środowiska społecznego osób z niepetnosprawnością intelektualną, Wydawnictwo Edukacyjne Akapit, Torun, 2010; J. Kruk-Lasocka, W. Antosz, Koszula i krawat. Obrazki wyłaniającej się dorosłości, Oficyna Wydawnicza „Impuls”, Kraków 2018; D. Krzemińska, Być parą z niepetnosprawnościa intelektualną. Studium mikroetnograficzne w kontekście teorii postkolonialnej Homiego K. Bhabhy, Oficyna Wydawnicza „Impuls”, Kraków 2019. 
by those experiencing such acceptance and support from their families of origin show that it means a lot to them and is an important factor that boosts their sense of self-determination and mental wellbeing.

Being an example of interpretative inquiry into the role of subjectivity and emancipation of the marginalized individuals, the inquiry into experiences and the significance attached to them within the group of individuals with disability shows not just their potential and needs but also large heterogeneity of those with intellectual disability and the need to constantly support their self-determination.

\section{Summary}

The present study seeks to demonstrate the place of the family of origin within romantic relationships among those with intellectual disability. On the one hand, the adopted research perspective and method have revealed personal experiences and their perceived significance and, on the other, has come with some limitations. Other research projects might want to use the method of biographical inquiry to provide a fuller picture of other aspects of the lives of individuals with intellectual disability or show the dynamics with families across various stages of relationships in question.

The analysis of the author's research and literature helped us to confirm the significance of the family of origin in the adult life of those with intellectual disability. Due to close emotional contacts, cultural customs (whereby it is the family that bears the greatest responsibility and is the source of support and care in the event of a disease, disability or dependability of its family member) and financial and sociological conditions (cohabitation, financial dependence), their relationships and bonds are particularly strong. It is very rare for these individuals to break away from their parents practically and mentally. Such a separation is usually due to the fact that parents are no longer alive or family members have drug or alcohol problems or violate law or suffer from disorders that pre- 
vent them from functioning properly in interpersonal relationships. Undoubtedly, to support independence and decision-making capacity in individuals with intellectual disability and promote their wellbeing and quality of life, their families of origin should be taken into account. Special education has an important mission to show the real capacity of those with intellectual disability to their families, debunk stereotypes and support them in addressing the challenges of raising a child with intellectual disability and preparing them for adulthood.

\section{References}

Charmaz K. (2009), Teoria ugruntowana. Praktyczny przewodnik po analizie jakościowej, PWN Warszawa.

English B., Tickle A., das Nair R. (2018), Views and Experiences of People with Intellectual Disabilities Regarding Intimate Relationships: A Qualitative Metasynthesis, "Sexsuality and Disability", No. 36, pp. 149-173.

Johnson K., Frawley P., Hillier L., Harrison L. (2002), Living safer sexual lives: research and action, "Tizard Learning Disability Review", No. 7(3), pp. 4-9.

Keith K.D., Schalock R.L. (2016), People speaking for themselves, [in:] R.L. Schalock, K.D. Keith (ed.), Cross-cultural quality of life: Enhancing the Lives of People With Intellectual Disability, American Association of Intellectual and Developmental Disabilities, Washington.

Kijak R. (2016), Dorośli z głębsza niepetnosprawnościa intelektualna jako partnerzy, matżonkowie i rodzice, Wydawnictwo Naukowe UP, Kraków.

Krause A., Żyta A., Nosarzewska S. (2010), Normalizacja środowiska społecznego osób z niepetnosprawnością intelektualna, Wydawnictwo Edukacyjne Akapit, Torun.

Kruk-Lasocka J., Antosz W. (2018), Koszula i krawat. Obrazki wyłaniającej się dorostości, Oficyna Wydawnicza „Impuls”, Kraków.

Krzemińska D. (2019), Być para z niepetnosprawnościa intelektualną. Studium mikroetnograficzne w kontekście teorii postkolonialnej Homiego K. Bhabhy, Oficyna Wydawnicza „Impuls”, Kraków.

Marton F. (1981), Phenomenograpgy - describing conceptions of the world around us, "Instructional Science" No. 10, pp. 177-200.

Marton F. (1986), Phenomenography - A research approach to investigating different understandings of reality, "Journal of Thought", vol. 21, No. 3, pp. 28-49.

Marton F. (1988), Phenomenography: Exploring different conceptions of reality, [in:] D.M. Fetterman (ed.), Qualitative approaches to evaluation in education: The silent scientific revolution, New York, Praeger, pp. 176-205. 
Marton F. (1994), Phenomenography, [in:] T. Husén, T.N. Postlethwaite (ed.), The International Encyclopedia of Education, Issue 2, vol. 8, Oxford, Pergamon, pp. 4424-4429.

Męczkowska A. (2003), Fenomenografia jako podejście badawcze w obszarze studiów edukacyjnych, „Kwartalnik Pedagogiczny” No. 3(189), pp. 71-89.

Myśliwczyk I. (2019), Uznanie dorostości człowieka z niepetnosprawnością. Studium socjopedagogiczne narracji osób z glębsza niepetnosprawnością intelektualną w stopniu glębszym, Oficyna Wydawnicza „Impuls”, Kraków.

Parchomiuk M. (2016), Seksualność człowieka z niepetnosprawnościa intelektualna, Oficyna Wydawnicza „Impuls”, Kraków.

Paulston R.G. (1993), Pedagogika porównawcza jako pole nakreślania konceptualnych map teorii paradygmatów, [in:] Z. Kwieciński, L. Witkowski (ed.), Spory o edukację. Dylematy i kontrowersje we wspótczesnych pedagogiach, Wyd. IBE-Edytor, WarszawaTorun, pp. 25-50.

Walker-Hirsch L. (2002), Building relationships/social and sexual development, [in:] W.I. Cohen L. Nadel M.E. Madnick (ed.), Down Syndrome. Visions for the $21^{\text {st }}$ century, A John Wiley\&Sons, Inc., New York.

White E., Barnitt R. (2000), Empowered or discouraged? A study of people with learning disabilities and their experience of engaging in intimate relationships. "British Journal of Occupational Therapy", No. 63(6), pp. 270-276.

Żyta A., Ćwirynkało K. (2020), Związki uczuciowe osób z niepetnosprawnościq intelektualna, Olsztyn, Wydawnictwo Uniwersytetu Warmińsko-Mazurskiego (paper in press). 